\title{
Diversity and species composition of diatom communities of Ardley Island, South Shetland Islands
}

\author{
Tereza Cahová*, Barbora Chattová
}

Department of Botany \& Zoology, Faculty of Science, Masaryk University, Kotlárská 2, 61137 Brno, Czech Republic

\begin{abstract}
The Antarctic diatom flora has been at the centre of interest of many studies in past decades. The present paper brings new information on the species richness, biogeography and community composition of diatoms on the Ardley Island, South Shetland Islands. One fresh-water and ten soil samples had been collected from the Antarctic Special protected area (ASPA) in the spring of 2019. The following analysis revealed eighty-six diatom taxa in well-developed communities, dominated by Luticola muticopsis, L. truncata, Pinnularia australoschoenfelderi, P. austroshetlandica and P. borealis. According to the current biogeographical knowledge, the majority of species have restricted distribution among the Antarctic Realm; 46.5\% of them are reported from various islands of the Maritime Antarctic Region. Based on the dominance of species as Luticola muticopsis and L. truncata and their ecological preferences, we concluded that the species composition of the diatom communities is driven by high nutrient input from breeding seabirds and the moisture availability during the austral summer.
\end{abstract}

Key words: algae, Bacillariophyta, biogeography, Maritime Antarctica, species composition

DOI: $10.5817 / C P R 2021-1-4$

\section{Introduction}

Diatoms (Bacillariophyta) are a widespread group of microscopic autotrophic organisms characterized by their siliceous shell called a frustule. They are one of the most abundant algal groups in terrestrial and fresh-water ecosystems in the Antarctic Realm (Jones 1996, Vyverman et al. 2010). Due to the long-term resistance of diatom frustule to the environment's physicochemical factors, their assemblages often serve as valuable bio-indicators due to the narrow tolerances of most species site-specific characteristic such as moisture availability, periods of desiccation, $\mathrm{pH}$ or nutrients input (Smol and Stoermer 2010).

Received November 15, 2020, accepted June 14, 2021.

*Corresponding author: T. Cahová <cahova.tereza@gmail.com>

Acknowledgements: The authors would like to thank the Turkish Antarctic Program, ITU Polar Research scientific infrastructure and the crew of the Betanzos ship for their support. This study was carried under the auspices of the Presidency of Turkish Republic, supported by the Ministry of Industry and Technology, and coordinated by Istanbul Technical University (ITU) Polar Research Center (PolReC). Sincere thanks go to Bilge Tutak for issuing the scientific permit for entering the ASPA area. Korhan Özkan is thanked for all the help in the field. 
However, using diatoms as bio-indicators in the Antarctic Realm has been complicated in the past by the historically broad definition of diatom species which lead to "force-fitting" (Tyler 1996) the Antarctic species and giving them European or North American names, even though these species had a sufficient number of different features to allow separation as independent taxa.

Hand in hand with "force-fitting", the ubiquity hypothesis goes. Historically, microbial dispersal was assumed to be frequent and widespread accordingly to BaasBecking's (1934) famous statement: "Everything is everywhere, the environment selects". According to this hypothesis, some authors, such as Finlay (2002), argued that there are no restricted biogeographical distributions similar to macroscopic organisms for microbes due to their small sizes and correspondingly large microbial populations, which should make dispersal events quite common. Nonetheless, the studies from the past three decades suggested that diatom community composition may be influenced by both environmental selection and dispersal limitation. For example, Verleyen et al. (2009) investigated dispersal and local abiotic factors within 15 regional datasets of lake diatom communities from Eurasia, Africa and Antarctica. Local abiotic factors explained the variability of diatom community composition, yet there was no or just a little significance of dispersal on larger geographic distances $(>2000 \mathrm{~km})$ observed.

The Antarctic Realm is one of eight terrestrial biogeographical regions. It is comprised of three distinct biogeographi-

\section{Material and Methods}

\section{Study site}

Ardley Island $\left(62^{\circ} 13^{\prime} \mathrm{S}, 58^{\circ} 56^{\prime} \mathrm{W}\right)$ is a small-area island ( $2 \mathrm{~km}$ long, $1.5 \mathrm{~km}$ wide) located in Maxwell Bay, southwest of King cal sub-regions that can be defined both geographically and climatically: sub-Antarctic Region, the Maritime Antarctic Region and the Continental Antarctic Region. The Maritime Antarctic Region consists of the regions west of the Antarctic Peninsula extending south to Marguerite Bay, including the South Shetland Islands, S. Orkney, and S. Sandwich and Bouvet Islands (Convey 2010).

Diatom flora of South Shetland Islands has been studied in past decades by Jones et al. (1993), Kawecka and Olech (1993), Hanson and Håkasson (1994), Fermani et al. (2007), Zidarova (2008), Kopalová and Van de Vijver (2013). However, only two algological studies were published from the Ardley Island so far (both together with the result of the survey of King George Island), and neither of those studies was explicitly focused on diatoms. Borchhardt et al. (2017) found 127 species of algae in total, only 56 species belonging to Heterokontophyta. Among them, 49 species of diatoms were found, some of them were not yet identified even on the genus level. Silva et al. (2019a) focused on terrestrial diatoms associated with macroscopic algae Prasiola crispa (Lightfoot) Kützing, and they found 23 species in 6 samples in total.

The objective of the present study is to identify the species richness and composition of diatom communities of the Ardley Island. Furthermore, to estimate the most significant ecological factors driving the species composition according to the ecological preferences of different diatom species.

George Island in South Shetland Archipelago (Fig. 1), separated from the Antarctic Peninsula by the Bransfield Strait 
and from South America by the Drake Passage. At low tide, a narrow sandspit connects the Ardley Island to King George Island. The island raises about $70 \mathrm{~m}$ above sea level and is evenly vegetated, with various communities composed of mosses and lichens, covering about $59 \%$ of its ice-free area (Andrade et al. 2018). The Ardley Island has the mildest climate of the Antarctic Region due to the influence of the Antarctic Circumpolar Current. According to the data from the Russian Bellingshausen Station at Collins Harbour, King George Island, there is an annual mean air temperature of $-2.5^{\circ} \mathrm{C}$ and mean precipitation of $701.3 \mathrm{~mm}$ per year (Borchhardt et al. 2017). There is one permanent water body on the Island, the Ardley Lake meanders on the partially frozen soils, creating temporary bogs and saturated wa- ter conditions. In the summer, the island is free of ice and hosts several thousands of breeding seabirds, contributing to an enhanced biotic influence. It has been estimated that during the breeding period, 139 tons of 'birds' droppings accumulate and are deposited on the island (Sun and Xie 2001). The Ardley Island hosts one of the largest breeding gentoo penguin (Pygoscelis papua) colonies (with c. 5000 pairs) in the Antarctica, alongside about 200 breeding pairs of Adélie penguins ( $P$. adeliae) and more than 50 breeding pairs of chinstrap penguins ( $P$. antarctica, Roberts et al. 2017). Due to the diversity of seabirds breeding on the island and the size of those colonies, the entire Ardley Island has been designated as Antarctic Special Protected Area ([1]-ASPA No.150, ATCM 2009).

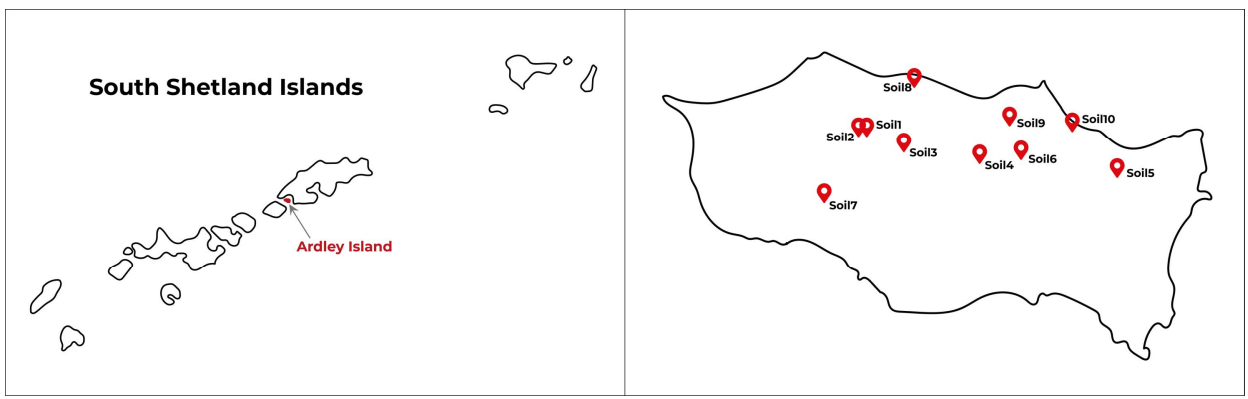

Fig. 1. Geographic location of studied island. Geographic location of Ardley Island among South Shetland Islands. Map of Ardley Island with locations of the samples.

\section{Sampling}

Sampling was carried out on February $3^{\text {rd }}, 2019$, and the area was entered with a permit number 32-2019. Small quantities (ten replicates of $10 \mathrm{~g}$ ) of soil were collected in PVC bottles and plastic bags. $5 \mathrm{~g}$ of the sample was fixed with $3 \%$ formalin, and an additional $5 \mathrm{~g}$ was preserved for further cultivation. One fresh-water epipelic sample $(20 \mathrm{ml})$ was taken from the littoral zone of the lake using a plastic pipette. Each sample was geographically localized using GPS and was accompanied by the sampling site description. The sampling resulted in ten soil samples from all over the island and one fresh-water sample (see Table 1). 


\begin{tabular}{|c|c|c|}
\hline Sample & Sample characterization & GPS \\
\hline Ardley soil1 & $\begin{array}{l}\text { slightly wet soil under the soil crust with dead } \\
\text { mosses }\end{array}$ & $\begin{array}{l}\text { S } 62^{\circ} 12^{\prime} 39.8^{\prime \prime} \\
\text { W } 58^{\circ} 56^{\prime} 17.1^{\prime \prime}\end{array}$ \\
\hline Ardley soil2 & slightly wet soil from a rock crack & $\begin{array}{l}\text { S } 62^{\circ} 12^{\prime} 39.9^{\prime \prime} \\
\text { W } 58^{\circ} 56^{\prime} 18.0^{\prime \prime}\end{array}$ \\
\hline Ardley soil3 & wet soil next to a seepage & $\begin{array}{l}\text { S } 62^{\circ} 12^{\prime} 41.5^{\prime \prime} \\
\text { W } 58^{\circ} 56^{\prime} 07.5^{\prime \prime}\end{array}$ \\
\hline Ardley soil4 & wet soil in a slope & $\begin{array}{l}\text { S } 62^{\circ} 12^{\prime} 42.8^{\prime \prime} \\
\text { W } 58^{\circ} 55^{\prime} 49.3^{\prime \prime}\end{array}$ \\
\hline Ardley soil5 & wet soil in a penguin colony & $\begin{array}{l}\text { S } 62^{\circ} 12^{\prime} 44.4^{\prime \prime} \\
\text { W } 58^{\circ} 55^{\prime} 16.1^{\prime \prime}\end{array}$ \\
\hline Ardley soil6 & $\begin{array}{l}\text { slightly wet soil from a hill above the penguin } \\
\text { colony }\end{array}$ & $\begin{array}{l}\mathrm{S} 62^{\circ} 12^{\prime} 42.4^{\prime \prime} \\
\text { W } 58^{\circ} 55^{\prime} 39.2^{\prime \prime}\end{array}$ \\
\hline Ardley soil7 & dry soil near Lake 1 & $\begin{array}{l}\text { S } 62^{\circ} 12^{\prime} 47.2^{\prime \prime} \\
\text { W } 58^{\circ} 56^{\prime} 26.9^{\prime \prime}\end{array}$ \\
\hline Ardley soil8 & dry soil from an abandoned penguin rookery & $\begin{array}{l}\text { S } 62^{\circ} 12^{\prime} 34.1^{\prime \prime} \\
\text { W } 58^{\circ} 56^{\prime} 05.1^{\prime \prime}\end{array}$ \\
\hline Ardley soil9 & wet soil in a penguin colony & $\begin{array}{l}\mathrm{S} 62^{\circ} 12^{\prime} 38.6^{\prime \prime} \\
\mathrm{W} 58^{\circ} 55^{\prime} 42.0^{\prime \prime}\end{array}$ \\
\hline Ardley soil10 & wet soil next to a pool in the penguin colony & $\begin{array}{l}\text { S } 62^{\circ} 12^{\prime} 39.2^{\prime \prime} \\
\text { W } 58^{\circ} 55^{\prime} 26.9^{\prime \prime}\end{array}$ \\
\hline
\end{tabular}

Table 1. Characteristics of Ardley Island' samples with GPS coordinates.

\section{Permanent slides preparation and observation of diatoms}

For clear identification of species according to the valve morphology. The samples were prepared following the modified method described in Van der Werff(1955). A small amount of all samples was cleaned by adding $37 \%$ hydrogen peroxide and heated up to $80^{\circ} \mathrm{C}$ for about 8 hours. The reaction was completed by adding $\mathrm{KMnO}_{4}$. Samples prepared this way were centrifuged (three times 10 minutes at $3700 \mathrm{x}$ g) and diluted with distilled water to avoid excessive concentrations of diatom valves that may hinder reliable observations. A drop of the liquid was then dried on coverslips and adhered to a microscope slide with high refracting index medium Naphrax ${ }^{\circledR}$.

\section{Data analysis}

Species accumulation curve was computed from the abundances of individuals in samples. Classical agglomerative cluster-
In each sample, 400 diatom valves were identified and enumerated on random transects at $1000 \times$ magnification (oil immersion), using an Olympus BX53 microscope, equipped with Differential Interference Contrast (Nomarski) optics and the Olympus UC30 Imaging System. Slides were scanned after counting 400 valves in order to find rare species. Identification of species was based on numerous publications, but mainly on the following sources: Bulínová et al. (2018), Kohler et al. (2015), Kopalová et al. (2015), Levkov et al. (2012), Van de Vijver et al. (2011, 2014a), Van de Vijver and Mataloni (2008), Zidarova et al. (2016).

ing was employed to group diatom assemblages according to the Bray-Curtis dissimilarity using the unweighted per group 
average algorithm (UPGMA), resulting in a dendrogram. For statistical analyses, the $\mathrm{R}$ environment was used ([2]-R Core Team

\section{Results}

\section{Species composition and diversity}

The analysis of all 11 samples revealed 86 diatom taxa, including subspecies and varieties. Of all species, 56 was found only in soil and eight only in the fresh-water sample. In the only fresh-water sample, 31 diatom species were observed, while 8 of them $(26 \%)$ were explicitly found in this sample. In 10 soil samples, the amount of 78 species was recorded; 55 of them $(71 \%)$ were found only in soils.

Species from the sample taken at the littoral zone of the Ardley Lake belonged to 15 genera (Fig. 2). The most abundant genera were genus Nitzschia Hassal with four species and the genus Planothidium Round \& L.Bukhtiyarova, also with four species. The most abundant species from the Ardley Lake samples accounted for over $86 \%$ (346 valves) of all counted valves, while 24 species accounted for less than $1 \%$ of all counted valves. The dominant species in the Ardley Lake were Fragilaria cf. parva (Grunow) A. Tuji \& D. M. Williams (59.5\%), Nitzchia gracilis Hantzsch (13.0\%), Gomphonema maritimoantarcticum Van de Vijver, Kopalová, Zidarova \& Kociolek (5.3\%), Psammothidium papilio (D. E. Kellogg, Stuiver, T. B. Kel-

\section{Biogeography}

According to the known biogeographical distribution (Table 2), $46.5 \%$ of species showed restricted distribution connected to the Maritime Antarctic Region. Only 18.6\% of species are considered cosmopolitan so far, $12.8 \%$ are more typical for sub-Antarctic Regions, 9.3\% are present in both Maritime Antarctica and Continental Ant-
2020) with the packages vegan, cluster and ggplot2 (Oksanen et al. 2019, Maechler et al. 2019, Wickham 2016).

$\log$ \& G. H. Denton) K. Kopalová \& B. Van de Vijver in Kopalová \& al. (4.8\%) and Planothidium rostrolanceolatum Van de Vijver, Kopalová \& Zidarova (4.0\%).

Soil diatom communities were composed of a total of 78 species in 24 genera (Fig. 3). The most abundant was genus Pinnularia Ehrenberg with 12 species $(50 \%)$ and genus Luticola D. G. Mann with 11 species $(46 \%)$. The five most abundant species in soils accounted for 54\% of all counted valves, while 59 species had an abundance of less than 1\%. Dominant species of the Ardley Island' soil were Pinnularia borealis Ehrenberg (20.0\% of counted valves), Luticola muticopsis (Van Heurck) D. G. Mann (9.9\%), Staurosira pottiezii Van de Vijver (9.4\%), Luticola truncata Kopalová \& Van de Vijver (7.4\%) and Pinnularia subantarctica var. elongata (Manguin) Van de Vijver \& Le Cohu (7.1\%).

The species accumulation curve (Fig. 4) does not show any flattening towards its end, indicating that the number of samples taken in this study was insufficient to evaluate the diatom species richness of the Ardley Island.

arctica Regions, and one species (1.2\% of found species) is common for Maritime and sub-Antarctic Regions. For ten species forming $9.3 \%$ of all, the biogeographical distribution remains unknown, primarily due to the taxonomical uncertainty in the identification of those species. 

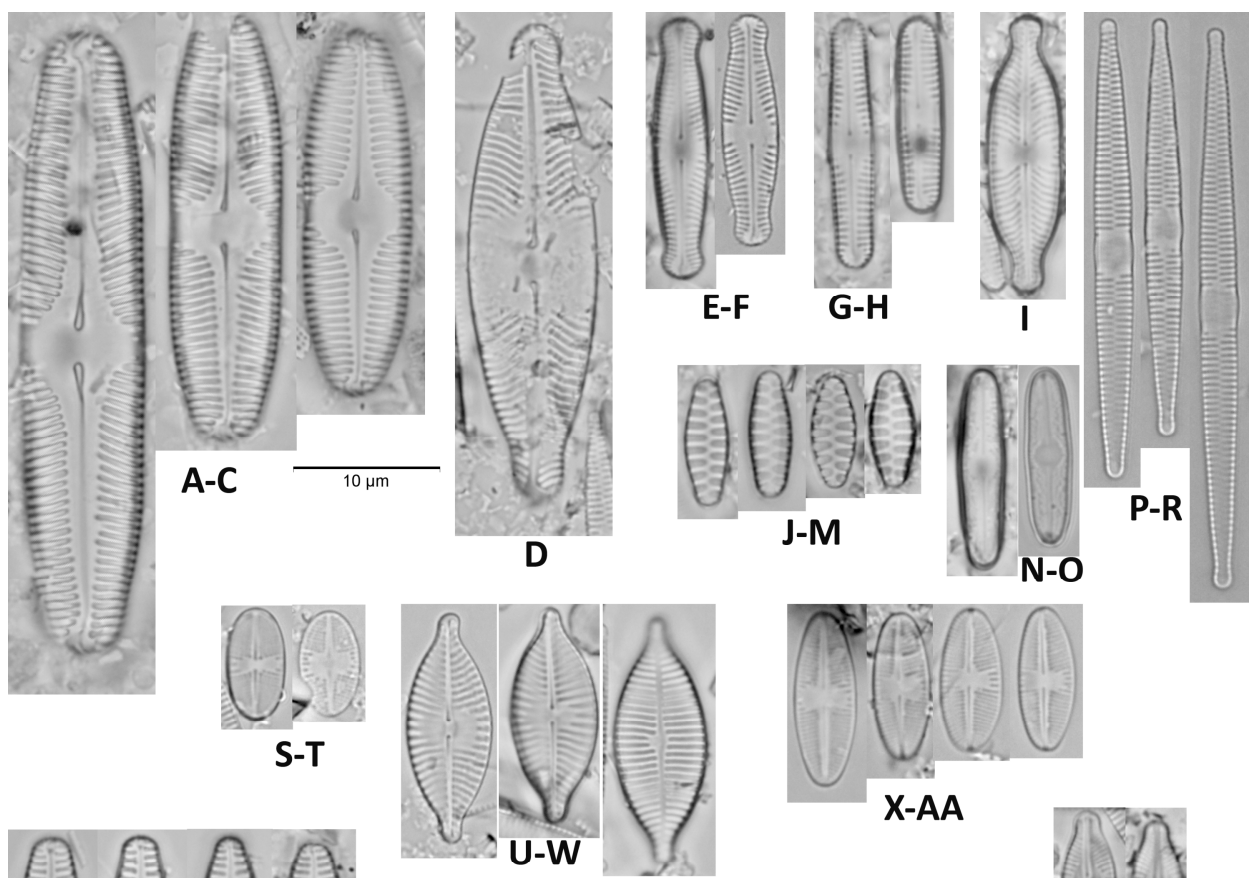
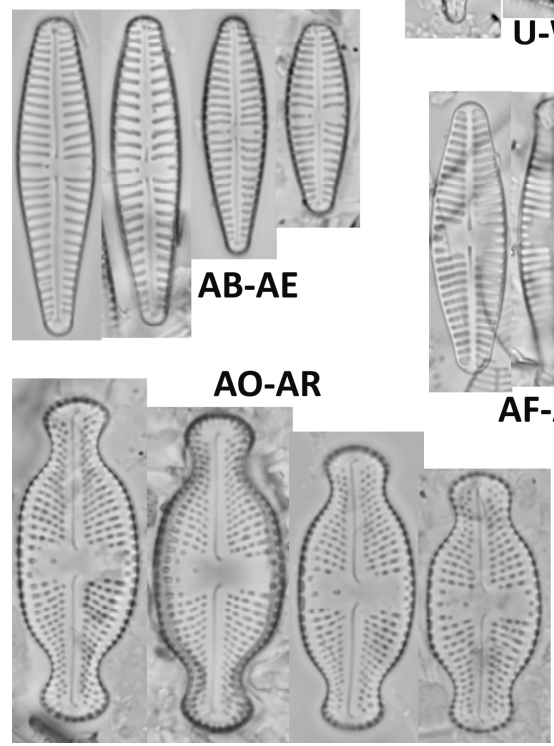

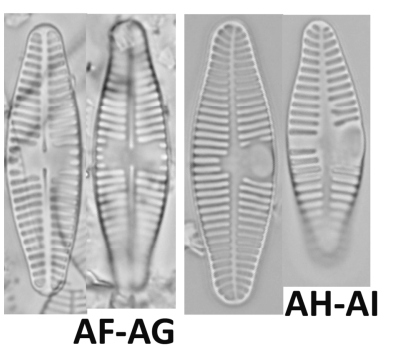

AS-AT

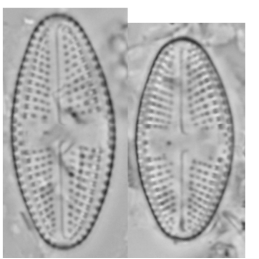

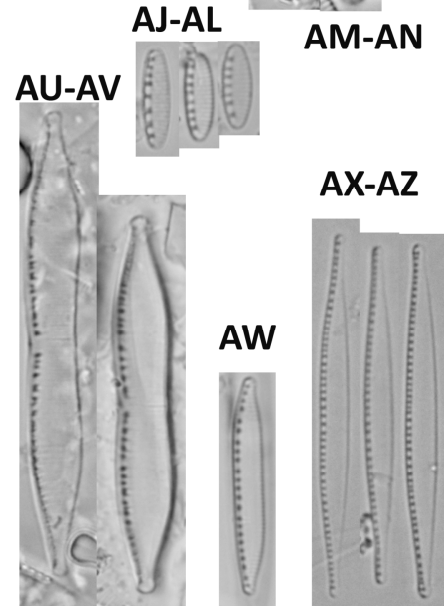

Fig. 2. LM micrographs of taxa found in the lake on Ardley Island.

Note: A-C: Pinnularia australomicrostauron. D: Pinnularia australoshetlandica. E-F: Chamaepinnularia krookiformis. G-H: Chamaepinnularia gerlachei. I: Placoneis australis. J-M: Staurosirella frigida. $\mathbf{N}-\mathbf{O}$ : Brachysira minor. P-R: Fragilaria ef. parva. S-T: Psammothidium subatomoides. U-W: Planothidium australe. $\mathbf{X}-\mathbf{A A}$ : Psammothidium papilio. AB-AE: Gomphonema maritimo-antarcticum. AF-AG: Planothidium rostrolanceolatum raphe valves. AH-AI: Planothidium rostrolanceolatum rapheless valves. AJ-AL: Nitzschia soratensis. AMAN: Microcostatus naumannii. AO-AR: Luticola muticopsis. AS-AT: Luticola subcrozetensis. AU-AV: Nitzschia homburgiensis. AW: Nitzschia kleinteichiana. AX-AZ: Nitzschia gracilis. Scale bar represents $10 \mu \mathrm{m}$. 

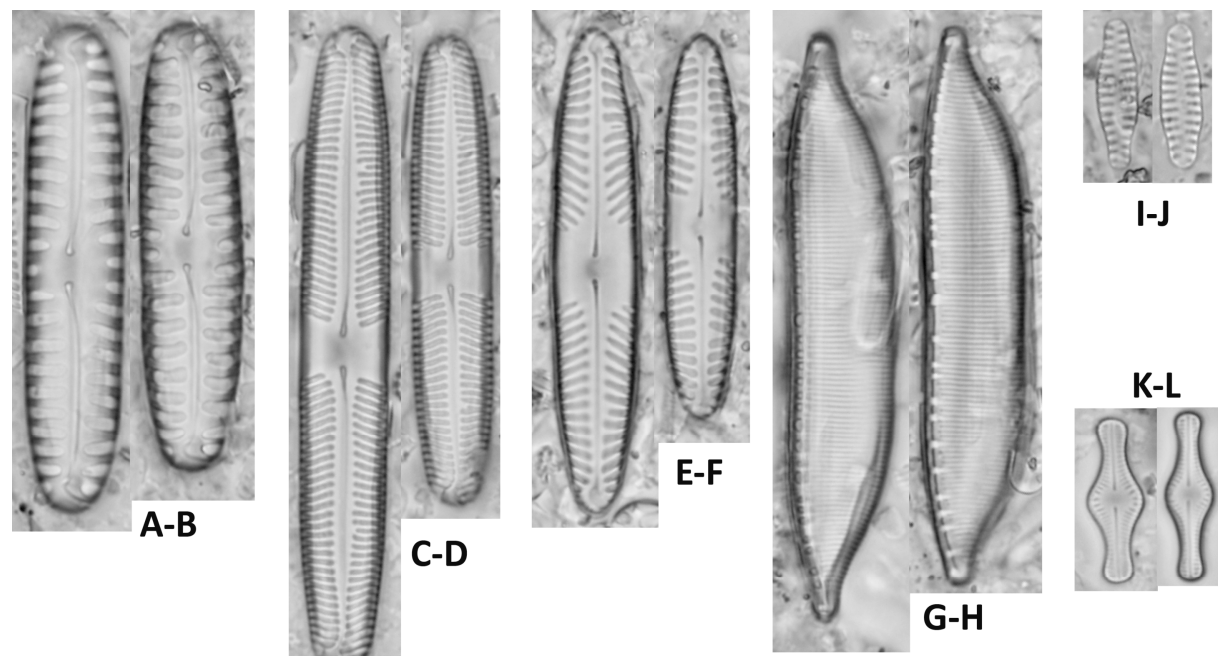

\section{C-D}
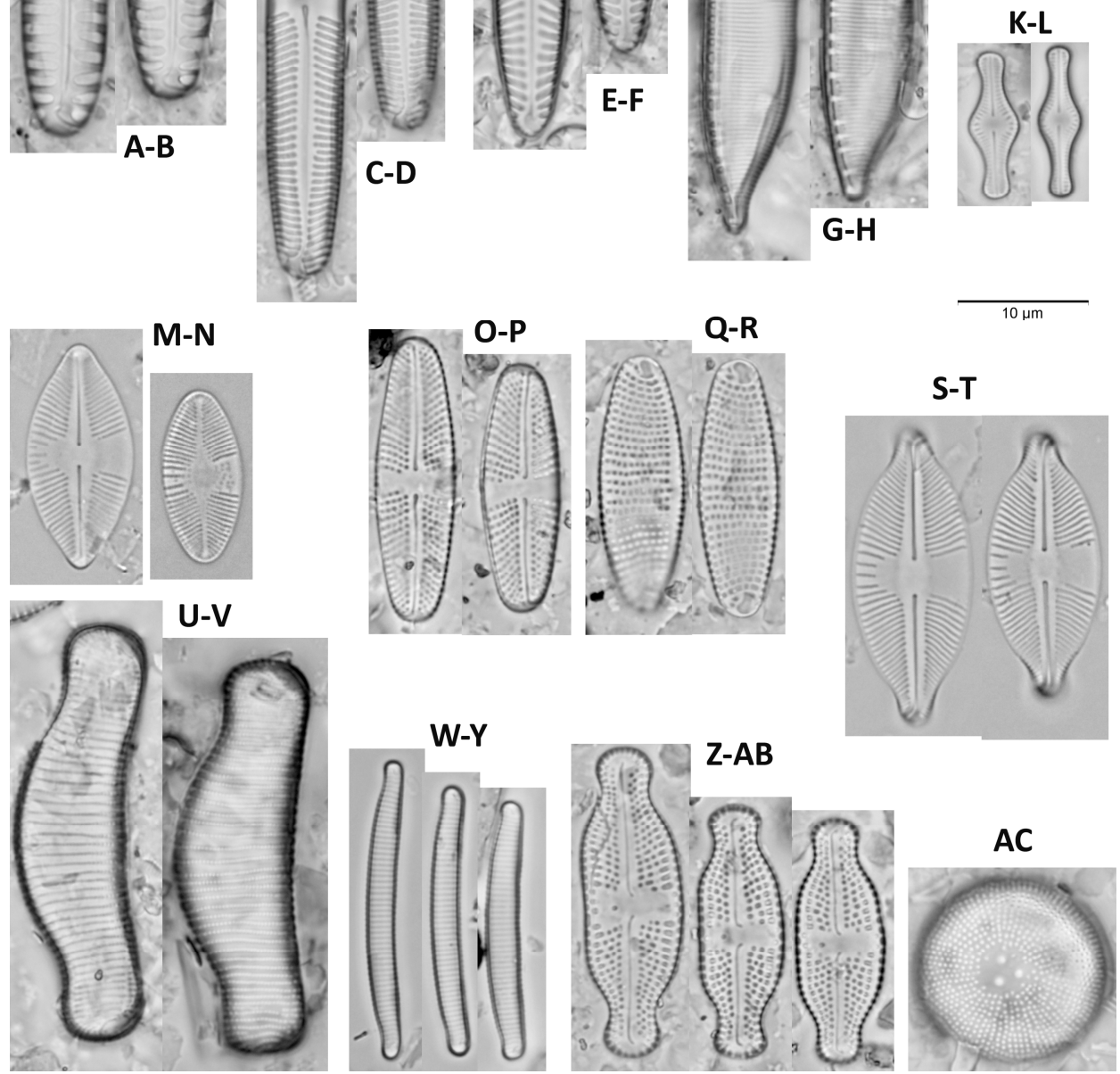

Fig. 3. LM micrographs of the typical taxa found in soils on Ardley Island.

Note: A-B: Pinnularia borealis. C-D: Pinnularia subantarctica var. elongata. E-F: Pinnularia australoschoenfelderi. G-H: Hantzschia acuticapitata. I-J: Staurosira pottiezii. K-L: Humidophila tabellariaeformis. M-N: Psammothidium germainii. O-P: Achnanthes taylorensis raphe valves. Q-R: Achnanthes taylorensis rapheless valves. S-T: Psammothidium rostrogermainii. U-V: Eunotia ralitsae. W-Y: Eunotia pseudopaludosa. Z-AB: Luticola truncata. AC: Orthoseira roeseana. Scale bar represents $10 \mu \mathrm{m}$. 


\begin{tabular}{|c|c|c|c|}
\hline Species & Biogeography & Species & Biogeography \\
\hline Achnanthes coarctata & $\mathrm{C}$ & Luticola doliiformis & MA \\
\hline Achnanthes muelleri & SA/MA/A & Luticola muticopsis & $\mathrm{SA} / \mathrm{MA}$ \\
\hline Achnanthes taylorensis & MA/A & Luticola permuticopsis & $\mathrm{C}$ \\
\hline Brachysira minor & MA & Luticola pusilla & MA \\
\hline Eunotia pseudopaludosa & SA/MA & Luticola sp. & $\mathrm{U}$ \\
\hline Eunotia ralitsae & MA & Luticola subcrozetensis & SA/MA \\
\hline Fragilaria cf. parva & $\mathrm{U}$ & Luticola truncata & MA \\
\hline Gomphonema maritimo- & MA & Luticola vermuelenii & MA \\
\hline $\begin{array}{l}\text { antarcticum } \\
\text { Halamphora }\end{array}$ & & Luticolacf. katkae & $\mathrm{U}$ \\
\hline oligotraphenta & $C$ & $\begin{array}{l}\text { Microcostatus } \\
\text { australoshetlandicus }\end{array}$ & MA \\
\hline Hantzschia abundans & $\mathrm{C}$ & $\begin{array}{l}\text { australosnetlanalcus } \\
\text { Microcostatus }\end{array}$ & \\
\hline Hantzschia amphioxys & $\mathrm{C}$ & naumannii & $\mathrm{C}$ \\
\hline $\begin{array}{l}\text { Hantzschia } \\
\text { hyperaustralis }\end{array}$ & MA & Muelleria aequistriata & MA \\
\hline Hantzschia incognita & MA & Muelleria aff. kristinae & $\mathrm{U}$ \\
\hline Hantzschiaacuticapitata & MA & Muelleria aff. nogae & $\mathrm{U}$ \\
\hline Humidophila aff. nienta & $\mathrm{U}$ & Muelleria algida & MA \\
\hline Humidophila arcuata & $\mathrm{AM} / \mathrm{SA} / \mathrm{MA} / \mathrm{A}$ & $\begin{array}{l}\text { Muelleria sabbei } \\
\text { Navicula }\end{array}$ & MA \\
\hline Humidophila australis & MA & $\begin{array}{l}\text { Navicula } \\
\text { australoshetlandica }\end{array}$ & MA \\
\hline Humidophila & MA & Navicula bicephaloides & SA/MA \\
\hline Humidophila & $M \triangle / A$ & Navicula gregaria & $\mathrm{C}$ \\
\hline inconspicua & $\operatorname{VIA} / \mathrm{A}$ & Navicula romanedwardii & MA \\
\hline Humidophila keiliorum & MA & Nitzschia gracilis & $\mathrm{C}$ \\
\hline $\begin{array}{l}\text { Humidophila } \\
\text { sceppacuerciae }\end{array}$ & MA & Nitzschia homburgiensis & C \\
\hline Humidophila & MA & Nitzschia kleinteichiana & MA \\
\hline tabellariaeformis & IVIA & Nitzschia paleacea & $\mathrm{C}$ \\
\hline $\begin{array}{l}\text { Humidophila } \\
\text { vojtajarosikii }\end{array}$ & MA & Nitzschia soratensis & $\mathrm{C}$ \\
\hline Chamaepinnularia & MA & Orthoseira roeseana & $\mathrm{C}$ \\
\hline $\begin{array}{l}\text { australomediocris } \\
\text { Chamaepinnularia }\end{array}$ & MA & $\begin{array}{l}\text { Pinnularia } \\
\text { australoborealis }\end{array}$ & MA \\
\hline $\begin{array}{l}\text { gerlachei } \\
\text { Chamaepinnularia }\end{array}$ & IVIA & $\begin{array}{l}\text { Pinnularia } \\
\text { australodivergens }\end{array}$ & MA \\
\hline $\begin{array}{l}\text { krookiformis } \\
\text { Chamaepinnularia }\end{array}$ & $c$ & $\begin{array}{l}\text { Pinnularia } \\
\text { australomicrostauron }\end{array}$ & MA \\
\hline krookii & $\mathrm{C}$ & Pinnularia & MA \\
\hline Luticola australomutica & MA & $\begin{array}{l}\text { australorabenhorstii } \\
\text { Pinnularia }\end{array}$ & \\
\hline Luticola austroatlantica & MA & australoschoenfelderi & MA \\
\hline
\end{tabular}




\begin{tabular}{|c|c|}
\hline Species & Biogeography \\
\hline Pinnularia austroshetlandica & MA \\
\hline Pinnularia borealis & $\mathrm{C}$ \\
\hline $\begin{array}{l}\text { Pinnularia } \\
\text { borealis var. pseudolanceolata }\end{array}$ & MA \\
\hline Pinnularia microstauroides & MA \\
\hline Pinnularia subaltiplanensis & MA \\
\hline $\begin{array}{l}\text { Pinnularia subantarctica var. } \\
\text { elongata }\end{array}$ & $\mathrm{SA} / \mathrm{MA}$ \\
\hline Pinnularia subcarteri & MA \\
\hline Placoneis australis & MA \\
\hline Planothidium aff. renei & $\mathrm{U}$ \\
\hline Planothidium australe & MA \\
\hline Planothidium lanceolatum & $\mathrm{C}$ \\
\hline $\begin{array}{l}\text { Planothidium } \\
\text { rostrolanceolatum }\end{array}$ & $\mathrm{C}$ \\
\hline Psammothidium germainii & SA/MA \\
\hline $\begin{array}{l}\text { Psammothidium } \\
\text { germainioides }\end{array}$ & MA \\
\hline Psammothidium manguinii & $\mathrm{C}$ \\
\hline Psammothidium papilio & MA \\
\hline $\begin{array}{l}\text { Psammothidium } \\
\text { rostrogermainii }\end{array}$ & MA \\
\hline Psammothidium subatomoides & $\mathrm{C}$ \\
\hline Sellaphora antarctica & MA \\
\hline Stauroforma cf. inermis & $\mathrm{U}$ \\
\hline $\begin{array}{l}\text { Stauroneis aff. } \\
\text { pseudoschimanskii }\end{array}$ & $\mathrm{U}$ \\
\hline Stauroneis cf. acidojarensis & $\mathrm{U}$ \\
\hline Stauroneis huskvikensis & $\mathrm{SA} / \mathrm{MA}$ \\
\hline Stauroneis latistauros & MA \\
\hline Staurosira pottiezii & MA \\
\hline Staurosirella frigida & MA \\
\hline
\end{tabular}

Table 2. Taxonomical list of all observed taxa in this study with their known biogeographical distribution. Note:

C - cosmopolitan;

CA - Continental Antarctica;

MA - Maritime Antarctica;

SA - sub-Antarctica;

$\mathrm{U}$ - unknown.

\section{Dendrogram}

According to the dendrogram based on the Bray-Curtis dissimilarity of samples (Fig. 5), the fresh-water sample is showing clearly different species composition. In this sample, typical fresh-water species of diatoms such as Fragilaria cf. parva, Nitzschia gracilis or Gomphonema maritimoantarcticum, dominate. 


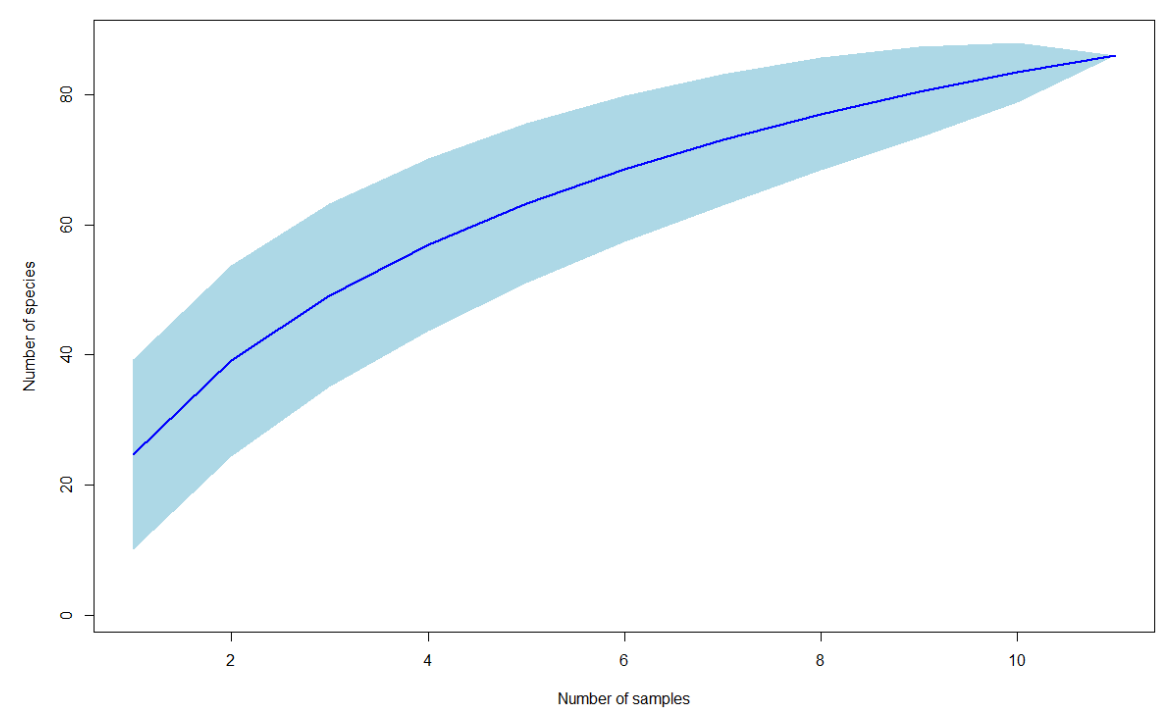

Fig. 4. Species accumulation curve.

Soil samples can be clearly divided into three major groups, and one sample standing aside those groups. The first group is formed with two samples abbreviated Soil2 and Soil3 in the following text. Diatom communities of those two samples were composed mainly of Nitzschia kleinteichiana Hamsher, Kopalová, Kociolek, Zidarova \& Van de Vijver, Staurosira pottiezii and Gomphonema maritimo-antarcticum. Such community composition very likely refers to temporary waterbodies or very wet soils.

The second groups of samples Soill and Soil6 are characterized by total dominance of Pinnularia borealis, accompanied by Pinnularia australoschoenfelderi Zidarova, Kopalová \& Van de Vijver and P. austroshetlandica (G. W. F.Carlson) A. Cleve. The presence of all these Pinnularia species shows the presence of wet substrate influenced by the biogenic input.

Third and the largest is a group of samples, which have similar composition dominated by Luticola and Pinnularia species and can be divided into two subgroups. The first sub-group is composed of samples Soil8, Soil9 and Soil10. For these samples, the dominance of Pinnularia borealis and Luticola truncata is characteristic, together with Luticola muticopsis. The L. muticopsis is a species of soils strongly influenced by animals, and it is less abundant only in sample Soil8. This sample was collected in an abandoned penguin nest. Thus the nutrients income can be lower than in the other two samples. The second sub-group is formed by samples Soil4 and Soil5. The species composition of these samples is similar to the previous one with the dominance of Luticola muticopsis and L. truncata, nevertheless, they are accompanied by Pinnularia subantarctica var. elongata, also a species typical for samples influenced by animals and often found in mosses.

Sample Soil7 stands aside from other soil samples due to the dominance of Eunotia pseudopaludosa Van de Vijver, De Haan \& Lange-Bertalot, referring to the temporarily flooded soil or very wet soils during the year. Eunotia is here accompanied by Pinnularia borealis and $P$. austroshetlandica, showing the strong influence of animals. 


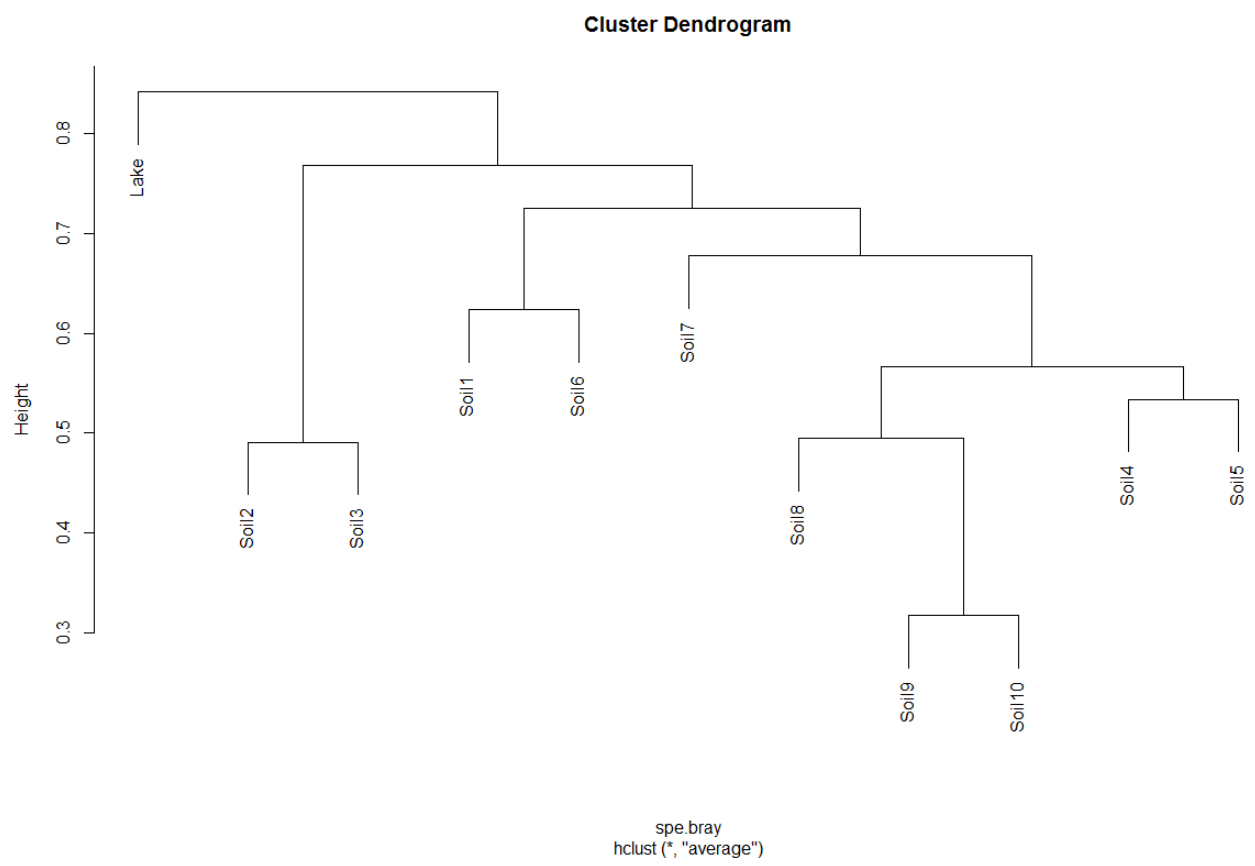

Fig. 5. Cluster dendrogram of Ardley Islands' samples.

\section{Discussion}

\section{Species composition and biogeography}

The first study of algae on the Ardley Island (Borchhardt et al. 2017) was focused on soil crusts of algae and lichens. Among 106 algal species found during the study, there were 42 species of diatoms in two samples from the Ardley Island, of which 17 could not be identified to the species level and 7 to the genus level. The second study was (Silva et al. 2019a) focused on microscopic algae associated with Prasiola crispa. There were only six diatom species observed in the sample from the Ardley Island. Although part of the observed flora is the same, several taxa formerly identified as cosmopolitan have now been described as separate species, most of which have restricted distribution among the Antarctic Realm. For example, Luticola contii Zidarova, Z. Levkov \& Van de Vijver and L. olegsakharovii Zidarova,
Z. Levkov \& Van de Vijver, both reported from several islands of South Shetlands (Zidarova et al. 2014), still have unsure distribution due to their confusion with Luticola nivalis (Ehrenberg) D. G. Mann, even though there are clearly different features visible under the light microscope, allowing them to be reliably distinguished.

Apart from taxonomic changes, more differences can be pointed out between the studies. Some genera, such as Chamaepinnularia Lange-Bertalot \& Krammer, Humidophila (Lange-Bertalot \& Werum) R. L. Lowe, Kociolek, J. R. Johansen, Van de Vijver, Lange-Bertalot \& Kopalová or Muelleria (Frenguelli) Frenguelli, often reported from the Antarctic Realm are missing in Borchhardt et al. (2017). On the other hand, several taxa that are listed could not be found in the present study, spe- 
cifically Gomphonema olivaceum (Hornemann) Ehrenberg, Pinnularia divergentissima (Grunow) Cleve or Planothidium linkei (Hustedt) Lange-Bertalot. These dissimilarities may exist due to the differences in sampling strategy or may result from species misidentification. For example, Planothidium linkei is morphologically similar to Planothidium australe (Manguin) Le Cohu, reported from Kerguelen Archipelago or other islands of South Shetlands (Schmidt et al. 1990, Oppenheim 1994, Zidarova et al. 2016, Silva et al. 2019b). However, from P. linkei, P. australe is distinguished by the configuration of the central area of the valve without raphe and by the number of pores within the striae (Le Cohu 2005). These differences can be caused by broad species concept in the past, that lead to consideration many species as cosmopolitan and ecological generalist. Eventually, it can be caused by confusion with cryptic and pseudo cryptic species common in many taxa so far considered cosmopolitan.

Among species reported in both previously published works, there were two dominants of the Ardley 'Islands' diatom communities, also found during this study. Fragilaria cf. parva, dominant species of the Ardley Lake, is a widespread taxon in the Maritime Antarctic Region, often forming large population in a broad variety of habitats, ranging from wet terrestrial moss vegetation to large lakes, rivers and pools (Zidarova et al. 2016). The species was commonly reported from Antarctica as Fragilaria capucina (Kawecka and Olech 1993, Kopalová et al. 2013). The Antarctic populations show a morphologically highly variable taxon, closely resembling Fragilaria parva in Tuji and Williams (2008). However, the taxon is different in the asymmetrical central area and has higher number of striae (Zidarova et al. 2016). The genus Fragilaria is often considered to be a pioneer species linked to rapid changes in water chemistry, mainly trophic status fluctuations (Stabell 1985,
Denys 1990). Kopalová et al. (2013) discussed that Fragilaria taxa at Ulu Peninsula could be benefiting from nutrient releases after ice and snow melting. On the Ardley Island, the factor influencing Fragilaria cf. parva is temporary nutrients income during birds breeding season. In soils, the most abundant species was Pinnularia borealis, a species widespread in terrestrial habitats and ephemeral waterbodies, often forming large populations (Zidarova et al. 2016). P. borealis is a complex of several taxa, currently considered cosmopolitan (Pinseel et al. 2020). So far, 68 different varieties and forms have been described (Kociolek et al. 2020) However, recent studies brought to light the evidence of 126 genetically separated species with even higher diversity, up to 415 species estimated (Souffreau et al. 2013, Pinseel et al. 2019, 2020).

Based on observation of species similar to taxa reported from the outside of Antarctics, such as Planothidium australe or Luticola olegsakharovii, it is not surprising that several diatom studies (Jones 1996, Van de Vijver and Beyens 1999) concluded that the diatom flora of the Antarctic Realm is merely composed of cosmopolitan species. However, with $60.5 \%$ of the observed species in this study having the distribution restricted to the Antarctic Realm, it is clear that these statements can no longer be accepted. This conclusion is also supported by other recent studies (Kociolek et al. 2017, Kociolek 2019, Pinseel et al. 2020).

The largest proportion of species has typical Maritime Antarctic distribution, and just a few species ( 8 taxa) is shared with Continental Antarctica. These species, for example, Achnanthes taylorensis D. E. Kellogg, Stuiver, T. B. Kellogg \& G.H.Denton, are also present on the James Ross Island (Kopalová et al. 2012, 2013). This fact could be explained by long-range transport connected to the general sea and air circulation (Marshal and Chalmers 1997). 


\section{Ecology of diatom communities}

From our data, it follows that the composition of diatom communities of the Ardley Island is influenced mainly by two major environmental factors: water availability and nutrients. Water availability during the austral summer influences the species composition of diatoms in soils of the Ardley Island. The differences are apparent between the Soil2, Soil3 and Soil7 and other soil samples. In the case of the first two, Staurosira pottiezii, species preferring small, shallow, usually temporary pools, dominate the community (Van de Vijver et al. 2014b) together with Nitzschia kleinteichiana and Gomphonema maritimoantarcticum, both typically occurring in a wide range of Antarctic fresh-water habitats (Van de Vijver et al. 2016, Hamsher et al. 2016). Additionally, sample Soil7 is dominated by Eunotia pseudopaludosa, species commonly found in damp soil in the pond margins or submerged bryophytes (Jüttner et al. 2018), which corresponds to the location of the sample near the Ardley Lake.

On the other hand, lower moisture levels are clear from the rest of the soil samples. Diatom communities of samples Soil1 and Soil6 points to the moist yet not submerged substrate because Pinnularia australoschoenfelderi was reported from a shallow pool and from under wet mosses (Zidarova et al. 2012), and so P. austroshetlandica prefers wet soil (Zidarova et al. 2016). P. borealis tends to choose truly terrestrial habitats, dry mosses and soils (Pinseel et al. 2020). However, samples of Pinnularia borealis are often accompanied with Luticola muticopsis and $L$. truncata. L. muticopsis is very often found in penguin rookeries (Van de Vijver et al.
2002, Van de Vijver and Mataloni 2008). L. truncata has been described from surfaces of stones sticking out of mosses in the tundra of James Ross Island (Kopalová et al. 2009).

As there are many seabirds breeding on the Ardley Island, covering the surface with a huge amount of organic material, the dominance of species preferring substrates rich in nutrients can be seen on the majority of observed diatom communities. $P$. subantarctica var. elongata is a species common in nutrient and salinity enriched areas, especially in penguin rookeries, where it often forms a typical community with Luticola muticopsis (Van de Vijver et al. 2002). Van de Vijver and Mataloni (2008) also reported special morphotype L. aff. muticopsis 2 from the centre of penguin rookery on the Deception Island, which mainly differs from L. muticopsis sensu stricto by larger valve dimensions (Van de Vijver and Mataloni 2008). These and other species preferring nutrient-rich substrate are more or less abundant in all samples collected on the Ardley Island.

This study brought more detailed information on the diatom species richness of the Ardley Island and species composition of Ardley Island. According to the current knowledge of the bioindicator status of species occurring in this study, we assume that the species composition is mainly driven by the nutrient input from breeding birds and water availability during the period of the austral summer. Nevertheless, it is clear from the species accumulation curve that for the description of the entire diatom flora of this Antarctic island, further research is needed.

\section{References}

Andrade, A. M. D, Michel, R. F. M., Bremer, U. F., Schaefer, C. E. G. R. and Simões, J. C. (2018): Relationship between solar radiation and surface distribution of vegetation in Fildes 
Peninsula and Ardley Island, Maritime Antarctica. International Journal of Remote Sensing, 39: 2238-2254.

BAAS-BECKING, L. G. M. (1934): Geobiologie of inleiding tot de milieukunde (No. 18-19). WP Van Stockum \& Zoon, The Hague.

Borchhardt, N., Schiefelbein, U., Abarca, N., Boy, J., Mikhailyuk, T., Sipman, H. J. and Karsten, U. (2017): Diversity of algae and lichens in biological soil crusts of Ardley and King George Islands, Antarctica. Antarctic Science, 29(3): 229-237.

Bulínová, M., Kochman-Kedziora, N., KopalovÁ, K. and Van de Vijver, B. (2018): Three new Hantzschia species (Bacillariophyta) from the Maritime Antarctic Region. Phytotaxa, 371 (3): 168-184.

Convey, P. (2010): Terrestrial biodiversity in Antarctica-Recent advances and future challenges. Polar Science, 4(2): 135-147.

DenYs, L. (1990): Fragilaria blooms in the Holocene of the Western coastal plain of Belgium. In: H. Simola (ed.): Proceedings of the $10^{\text {th }}$ diatom-symposim 1988. Koeltz Scientific Books, Koenigstein, pp. 397-406.

Fermani, P., Mataloni, G. and Van De Vijver, B. (2007): Soil microalgal communities on an antarctic active volcano (Deception Island, South Shetlands). Polar Biology, 30: 1381-1393.

FinlaY, B. J. (2002): Global dispersal of free-living microbial eukaryote species. Science, 296(5570): 1061-1063.

Hamsher, S., Kopalová, K., Kociolek, P. J., Zidarova, R. and Van DE Vijver, B. (2016): The genus Nitzschia on the South Shetland Islands and James Ross Island. Fottea, 16(1): 79-102.

HANSSON, L. A., HÅKASSON, H. (1994): Diatom community response along a productivity gradient of shallow Antarctic lakes. Polar Biology, 12: 463-468.

JONES, V. J. (1996): The diversity, distribution and ecology of diatoms from Antarctic inland waters. Biodiversity and Conservation, 5: 1433-1449.

Jones, V.J., JugGins, S. and Ellis-Evans, J. C. (1993): The relationship between water chemistry and surface sediment diatom assemblages in maritime Antarctic lakes. Antarctic Science, 5: 339-348.

JÜtTNer, I., VAN DE Vijver, B., Williams, D.M., Lange-Bertalot, H. and Ector, L. (2018): The genus Eunotia (Bacillariophyta) in the Falkland Islands and species-are relationships in subAntarctic islands. Diatom Research 33(4): 413-452.

Kawecka, B., Olech, M. (1993): Diatom communities in the Vanishing Creek and Ornithologist Creek, King George Island, South Shetlands, Antarctica. Hydrobiologia, 269/270: 327-333.

KocioleK, J. P. (2019): A worldwide listing and biogeography of fresh-water diatom genera: A phylogenetic perspective. Diatom Research, 33(4): 509-534.

Kociolek, J. P., Kopalová, K., Hamsher, S. E., Kohler, T. J., Van De Vijver, B., Convey, P. and MCKNiGHT, D. M. (2017): Fresh-water diatom biogeography and the genus Luticola an extreme case of endemism in Antarctica. Polar Biology, 40: 1185-1196.

Kociolek, J.P., Blanco, S., Coste, M., Ector, L., Liu, Y., Karthick, B., Kulikovskiy, M., Lundholm, N., Ludwig, T., Pot Apova, M., Rimet, F., SAbBe, K., SAla, S., SAR, E., Taylor, J., VAn DE ViJVer, B., Wetzel, C.E., Williams, D.M., WitKowski, A. and WitKowski, J. (2020): DiatomBase. Accessed at http://www.diatombase.org on 2020-11-13

Kohler, T. J., Kopalová, K., Van De ViJver, B. and Kociolek, P. J. (2015): The genus Luticola D.G.Mann (Bacillariophyta) from the McMurdo Sound Region, Antarctica, with description of four new species. Phytotaxa, 208(2): 103-134.

KopalovÁ, K., VAN DE ViJVER, B. (2013): Structure and ecology of fresh-water benthic diatom communities from Byers Peninsula, Livingston Island, South Shetland Islands. Antarctic Science, 25(2): 239-253.

KopalovÁ, K., Elster, J., Nedbalová, L. and Van de Vijver, B. (2009): Three new terrestrial diatom species from seepage areas on James Ross Island (Antarctic Peninsula Region). Diatom Research, 24(1): 113-122.

Kopalová, K., Veselá, J., Elster, J., Nedbalová, L., Komárek, J. and Van de Vijver, B. (2012): Benthic diatoms (Bacillariophyta) from seepages and streams on James Ross Island (NW Weddel Sea, Antarctica). Plant Ecology and Evolution, 145: 190-208(19). 
Kopalová, K., Nedbalová, L., NÝvlt, D., Elster, J. and Van de Vijver, B. (2013): Diversity, ecology and biogeography of the fresh-water diatom communities from Ulu Peninsula (James Ross Island, NE Antarctic Peninsula). Polar Biology, 36: 933-948.

KopalovÁ, K., Kociolek, J.P., Lowe, R.L., Zidarova, R. and Van De ViJVer, B. (2015): Five new species of the genus Humidophila (Bacillariophyta) from the Maritime Antarctic Region. Diatom Research, 30(2): 117-131.

LE Cohu, R. (2005): Révision des principales espéîces dulçaquicoles d'Achnanthales (Bacillariophyta) des îles subantarctiques de Kerguelen. Algological Studies, 116: 79-114.

Levkov, Z., Metzeltin, D. and Pavlov, A. (2012): Luticola and Luticolopsis. Diatoms of Europe 7: 1-654.

Marshal, W. A., Chalmers, M. O. (1997): Airborne dispersal,of Antarctic terrestrial algae and cyanobacteria. Ecography, 20: 585-594.

Maechler, M., Rousseeuw, P., Struyf, A., Hubert, M. and Hornik, K. (2019): cluster: Cluster Analysis Basics and Extensions. R package version 2.1.0.

Oksanen, J., Guillaume Blanchet, F., Friendly, M., Kindt, R., Legendre, P., McGlinn, D., Minchin, P. R., O'Hara, R. B., Simpson, G. L., Solymos, P., Stevens, M. H. H., Szoecs, E. and Wagner, H. (2019): vegan: Community Ecology Package. R package version 2.5-4. https://CRAN.R-project.org/package=vegan

OpPENHEIM, D. (1994): Taxonomic studies of Achnanthes (Bacillariophyta) in freshwater marine antarctic lakes. Canadian Journal of Botany,72: 1735-1748.

Pinseel, E., Kulichová, J., Scharfen, V., Urbánková, P., Van De Vijver, B. and Vyverman, W. (2019): Extensive cryptic diversity in the terrestrial diatom Pinnularia borealis (Bacillariophyceae). Protist, 170: 121-140.

Pinseel, E., Janssens, S., Verleyen, E., Vanormelingen, P., Kohler, T., Biersma, E., Sabbe, K., VAN DE VIJVER, B. and Vyverman, W. (2020): Global radiation in a rare biosphere soil diatom. Nature Communications, 11: 2382. https://doi.org/10.1038/s41467-020-16181-0

Roberts, S. J., Monien, P., Foster, L. C., Loftfield, J., Hocking, E. P., Schnetger, B., Pearson, E. J., Juggins, S., Fretwell, P., Ireland, L., Ochyra, R., Haworth, A. R., Allen, C. S., Moreton, S. G., Davies, S. J., Brumsack, H. J., Bentley, M. J. and Hodgson, D. A. (2017): Past penguin colony responses to explosive volcanism on the Antarctic Peninsula. Nature Communication, 8: 14914. doi: 10.1038/ncomms 14914

SCHMidT, R., Mäusbacher, R. and MüLler, J. (1990): Holocene diatom flora and stratigraphy from sediment cores of two antarctic lakes (King George Island). Journal of Paleolimnology, 3: 55-74.

Silva, J. F., Oliveira, M. A., Anunciação, R. R, Silva, E. P., Alves, R. P., Schünemann, A. L., Victoria, F. C., de Albuquerque, M. P. and Pereira, A. B. (2019a): Distribution of aerophilous diatom communities associated with terrestrial green macroalgae in the South Shetland Islands, Maritime Antarctica. PLoS ONE, 14(12).

Silva, J. F., Oliviera, M. A., Alves, R. P., Cassol, A. P. V., Anunciação, R. R, Silva, E. P., Schünemann, A. L. and Pereira, A. B. (2019b): Geographic distribution of epilithic diatoms (Bacillariophyceae) in Antarctic lakes, South Shetland Islands, Maritime Antarctica Region. Check List, 15(5): 797-809.

Smol, J. P., Stoermer, E. F. (2010): The Diatoms: Applications for environmental and Earth sciences. Second Edition, Cambridge University Press. 66 p.

Souffreau, C., Vanormelingen, P., Van de Vijver, B., Isheva, T., Verleyen, E., SabBe, K. and VyVERMAN, W. (2013): Molecular evidence for distinct Antarctic lineages in the cosmopoltan terrestrial diatoms Pinnularia borealis and Hantzschia amphioxys. Protist, 164: 101-115.

Stabell, B. (1985): The development and succession of taxa within the diatom genus Fragilaria Lyngbye as a response to basin isolation from the sea. Boreas, 14: 273-286.

Sun, L., XIE, Z. (2001): Changes in lead concentration in Antarctic penguin droppings during the past 3,000 years. Environmental Geology, 40(10): 1205-1208.

TuJI, A., Williams, D. M. (2008): Typification and type examination of Synedra familiaris Kütz. and related taxa. Diatom. The Japanese Journal of Diatomology, 24: 25-29. 
TYLER, P. A. (1996): 13. Endemism in fresh-water algae, with special reference to the Australian region. Hydrobiologia, 336: 127-135. Springer, Dordrecht. https://doi.org/10.1007/BF00010826

VAN DE VIJVER, B., BEYENS, L. (1999): Biogeography and ecology of fresh-water diatoms in subAntarctica: A review. Journal of Biogeography, 26: 993-1000.

VAn DE ViJver, B., Mataloni, G. (2008): New and interesting species in the genus Luticola D.G.Mann (Bacillariophyta) from Decption Island (South Shetland Islands). Phycologia, 47(5): 451-467.

Van de Vijver, B., Frenot, Y. and Lange-Bertalot, H. (2002): Fresh-water diatoms from Ile de la Possession (Crozet Archipelago, Subantarctica). Bibliotheca Diatomologica, 51: 1-317.

VAN DE ViJver, B., ZidAROVA, R. and DE HAAN, M. (2011): Four new Luticola taxa (Bacillariophyta) from the South Shetland Islands and James Ross Island (Maritime Antarctic Region). Nova Hedwigia, 92(1-2): 137-158.

VAn DE Vijver, B., De HaAn, M. and Lange-Bertalot, H. (2014a): Revision of the genus Eunotia (Bacillariophyta) in the Antarctic Region. Plant Ecology and Evolution, 147(2): 256284.

Van De Vijver, B., Morales, E. and Kopalová, K. (2014b): Three new araphid diatoms (Bacillariophyta) from the Maritime Antarctic Region. Phytotaxa, 167(3): 256-266.

Van de Vijver, B., Kopalová, K., Zidarova, R. and Kociolek, P. J. (2016): Two new Gomphonema species (Bacillariophyta) from the Maritime Antarctic Region. Phytotaxa, 269(3): 209-220.

VAN DER WERFF, A. (1955): A new method for cleaning and concentrating diatoms and other organisms. Verhanhlungen der Internationalen Vereinigung für theoretische und angewandte. Limnologie, 12: 276-277.

Verleyen, E., Vyverman, W., Sterken, M., Hodgson, D. A., De Wever, A., Juggins, S., Van De Vijver, B., Jones, V. J., Vanormelingen, P., Roberts, D. and Flower, R. (2009): The importance of dispersal related and local factors in shaping the taxonomic structure of diatom metacommunities. Oikos, 118(8): 1239-1249.

Vyverman, W., Verleyen, E., Wilmotte, A., Hodgson D. A., Willems, A., Peeters, K., Van de Vijver, B., De Wever, A., Leliaert, F. and Sabbe, K. (2010): Evidence for widespread endemism among Antarctic micro-organisms. Polar Science, 4: 103-113.

WickHAM, H. (2016): ggplot2: Elegant Graphics for Data Analysis. Springer-Verlag New York.

ZidAROVA, R. (2008): Algae from Livingston Island (South Shetland Islands): A checklist. Phytologia Balcanica, 14: 11-37.

Zidarova, R., Kopalová, K. and VAn DE ViJver, B. (2012): The genus Pinnularia (Bacillariophyta) excluding the section Distantes on Livingston Island (South Shetland Islands) with the description of twelve new taxa. Phytotaxa, 44: 11-37.

Zidarova, R., LeVkov, Z. and VAN DE ViJver, B. (2014): Four new Luticola taxa (Bacillariophyta) from Maritime Antarctica. Phytotaxa, 170(3): 155-168.

Zidarova, R., KopalovÁ, K. and Van DE ViJver, B. (2016): Diatoms from the Antarctic Region I: Maritime Antarctica. Iconographia Diatomologica, 24. 509 p.

\section{Web sources / Other sources}

[1] ASPANo.150, ATCM 2009

ATCM (Antarctic Treaty Consultative Meeting) (2009): Management Plan for Antarctic Specially Protected Area No. 150: Ardley Island, Maxwell Bay, King George Island (25 de Mayo). XXXII Antarctic Treaty Consultative Meeting, Baltimore, 2009, Measure 9: 1-13.

[2] R Core Team (2020): R: A language and environment for statistical computing. R Foundation for Statistical Computing, Vienna, Austria. URL https://www.R-project.org/ 